\title{
Steroidal glycosides from the marine sponge Pandaros acanthifolium.
}

Nadja Cachet ${ }^{\mathrm{a}}$, Erik L. Regalado ${ }^{\mathrm{b}}$, Grégory Genta-Jouve ${ }^{\mathrm{a}}$, Mohamed Mehiri ${ }^{\mathrm{a}}$, Philippe Amade ${ }^{\mathrm{a}}$, Olivier P. Thomas, ${ }^{\mathrm{a}, *}$

${ }^{a}$ Laboratoire de Chimie des Molécules Bioactives et Arômes UMR 6001 CNRS, University of NiceSophia Antipolis, Faculté des Sciences Parc Valrose, 06108 Nice Cedex 2, France.

${ }^{b}$ Department of Chemistry, Center of Marine Bioproducts, Loma y 37 Alturas del Vedado, C.P. 10400 Havana, Cuba.

The first two authors contributed equally to this work

* Corresponding author: tel.:+33 4920761 34; fax: +33492076599

E-mail address: olivier.thomas@unice.fr

IMPORTANT: This is an uncorrected proof. Please, access to the published version:

http://dx.doi.org/10.1016/j.steroids.2009.03.009 


\begin{abstract}
The chemical composition of the Caribbean sponge Pandaros sp. was investigated and led to the isolation of seven new steroidal glycosides namely pandarosides A-D (1, 3, $\mathbf{4}$ and $\mathbf{6})$ along with the three methyl esters of pandarosides A, C, and D (2, 5 and 7). Their structures were characterized as $3 \beta$-[ $\beta$-glucopyranosyl- $(1 \rightarrow 2)$ - $\beta$-glucopyranosyloxyuronic acid]-16-hydroxy-

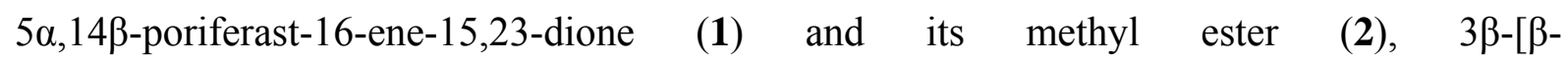
glucopyranosyloxyuronic acid]-16-hydroxy-5 $\alpha, 14 \beta$-poriferast-16-ene-15,23-dione (3), 3 $\beta$-[ $\beta$ glucopyranosyl-( $1 \rightarrow 2)$ - $\beta$-glucopyranosyloxyuronic acid]-16-hydroxy-5 $\alpha, 14 \beta$-cholest-16-ene15,23-dione (4) and its methyl ester (5), 33-( $\beta$-glucopyranosyloxyuronic acid)-16-hydroxy$5 \alpha, 14 \beta$-cholest-16-ene-15,23-dione (6) and its methyl ester (7) on the basis of detailed spectroscopic analyses, including 2D NMR and HRESI-MS studies. Pandarosides A-D and their methyl esters (1-7) are all characterized by a rare 2-hydroxycyclopentenone D-ring with a $14 \beta$ configuration.
\end{abstract}

Keywords: Marine sponge; Pandaros; steroidal glycosides; structure elucidation, stereochemistry 


\section{Introduction}

Saponins are an important class of natural products mainly found in terrestrial plants. They are scarcely found in the marine environment and echinoderms are the main source of this class of compounds [1]. Their presence in marine sponges was first discovered in the late 1980 ' [2,3]. Since then, triterpene glycosides only have been reported from the two genera Asteropus and Erylus [4,5].

As part of our ongoing work on the secondary metabolites of Caribbean marine sponges, we undertook the chemical study of a specimen of the marine sponge Pandaros sp. (Poecilosclerida, Microcionidae) collected at the Canyon rock off the Martinique coast. The order Poecilosclerida is known to produce a large diversity of complex guanidine alkaloids [6], and only acanthifolicin, a polyether carboxylic acid, has been isolated from Pandaros species [7].

Herein we report the isolation of seven steroidal glycosides named pandaroside A-D (1, 3, 4 and 6) and the methyl ester of pandarosides A, C and D (2, 6 and 7) as the major constituents of a Pandaros sp. sponge. Their structures were elucidated by extensive spectroscopic studies including 1D- and 2D-NMR experiments (COSY, HSQC, HMBC, and NOESY), as well as HRESI-MS analyses. All new compounds share the rare 2-hydroxycyclopent-2-enone D ring with a $14 \beta$ configuration. To our knowledge, Pandaros sp. is the first marine organism producing steroidal glycosides with such an aglycon nucleus.

\section{Experimental}

\subsection{General}

Optical rotations were measured on a Bellingham ADP220 polarimeter. CD spectra were measured using a JASCO J-810 spectropolarimeter. IR spectra were obtained with a PerkinElmer Paragon 1000 FT-IR spectrometer. UV measurements were performed on a Varian Cary 300 Scan UV-Visible spectrometer. Electrospray ionisation (ESI) mass spectra were obtained with a Bruker Esquire 3000 Plus spectrometer in the positive or negative mode. High-resolution mass spectra (HRESI-MS) were obtained from a LTQ Orbitrap mass spectrometer (Thermo Finnigan). NMR experiments were performed on a Bruker Avance 500 $\mathrm{MHz}$ spectrometer. Chemical shifts $(\delta$ in $\mathrm{ppm})$ are referenced to the carbon $\left(\delta_{\mathrm{C}} 49.15\right)$ and residual proton $\left(\delta_{\mathrm{H}} 3.31\right)$ signals of $\mathrm{CD}_{3} \mathrm{OD}$, the solvent with multiplicity (s singlet, d doublet, $\mathrm{t}$ triplet, $\mathrm{m}$ multiplet). HPLC separation and purification were carried out on a Waters 600 system equipped with a Waters 996 Photodiode Array detector coupled with a Sedex 55 ELSD (SEDERE, France), and a Waters 717 plus Autosampler. TLC was performed with 
Kieselgel $60 \mathrm{~F}_{254}$ (Merck glass support plates) and spots were detected after spraying with $10 \% \mathrm{H}_{2} \mathrm{SO}_{4}$ in EtOH reagent and heating.

\subsection{Biological material}

The marine sponge was collected off Martinique Island in Summer 2003 by SCUBA diving (Canyons de Babodie 14\%45,982 N, 61 $1^{\circ} 11,902 \mathrm{~W}$ ). A voucher specimen (ORMA8362) identified by Dr Jean Vacelet, has been deposited in the Centre d'Océanologie de Marseille (Endoume, France). The sponge was kept frozen from collection until the extraction process.

\subsection{Extraction and isolation}

The frozen sponge $(350 \mathrm{~g})$ was cut into pieces of about $1 \mathrm{~cm}^{3}$ and extracted with $\mathrm{MeOH} / \mathrm{CH}_{2} \mathrm{Cl}_{2}$ 1:1 at room temperature yielding $13 \mathrm{~g}$ of crude extract after solvent evaporation. The crude extract was fractionated by $\mathrm{RP}-\mathrm{C}_{18}$ flash chromatography (elution with a decreasing polarity gradient of $\mathrm{H}_{2} \mathrm{O} / \mathrm{MeOH}$ from 1:0 to $0: 1$, then $\mathrm{MeOH} / \mathrm{CH}_{2} \mathrm{Cl}_{2}$ from 1:0 to $0: 1)$. The $\mathrm{H}_{2} \mathrm{O} / \mathrm{MeOH} 1: 3$ fraction was further fractionated by $\mathrm{RP}_{-} \mathrm{C}_{18}$ column chromatography $\left(\mathrm{H}_{2} \mathrm{O} / \mathrm{MeOH}\right.$ from 95:5 to 0:100). The $\mathrm{H}_{2} \mathrm{O} / \mathrm{MeOH}$ 1:3 (195 mg) fraction was then subjected to $\mathrm{RP}-\mathrm{C}_{18}$ semi-preparative HPLC (Phenomenex, Luna $\mathrm{C}_{18}, 250 \times 10 \mathrm{~mm}$, $5 \mu \mathrm{m}$ ) with a gradient of $\mathrm{H}_{2} \mathrm{O} / \mathrm{MeOH} / \mathrm{TFA}$ (flow $3.0 \mathrm{~mL} \mathrm{~min}^{-1}$ from 28:72:0.1 to 20:80:0.1) and the subsequent mixtures were finally purified by analytical HPLC (Phenomenex, Gemini $\mathrm{C}_{6}$-phenyl, $\left.250 \times 3 \mathrm{~mm}, 5 \mu \mathrm{m}\right)$ with an isocratic mobile phase $\left(\mathrm{H}_{2} \mathrm{O} / \mathrm{CH}_{3} \mathrm{CN} /\right.$ formic acid, 60:40:0.1, flow $\left.0.5 \mathrm{~mL} \mathrm{~min}^{-1}\right)$ to afford pure compounds $1\left(3.5 \mathrm{mg}, 10^{-3} \% \mathrm{w} / \mathrm{w}\right), 2(4.8 \mathrm{mg}$, $\left.1.4 \times 10^{-3} \% \mathrm{w} / \mathrm{w}\right), 3\left(5.7 \mathrm{mg}, 1.6 \times 10^{-3} \% \mathrm{w} / \mathrm{w}\right), 4\left(1.7 \mathrm{mg}, 0.5 \times 10^{-3} \% \mathrm{w} / \mathrm{w}\right), 5\left(1.2 \mathrm{mg}, 0.3 \times 10^{-}\right.$ $\left.{ }^{3} \% \mathrm{w} / \mathrm{w}\right), 6\left(1.8 \mathrm{mg}, 0.5 \times 10^{-3} \% \mathrm{w} / \mathrm{w}\right)$, and $7\left(2.0 \mathrm{mg}, 0.6 \times 10^{-3} \% \mathrm{w} / \mathrm{w}\right)$.

Pandaroside $A$ (1): $3 \beta$-[ $\beta$-glucopyranosyl-(1 $\rightarrow 2)-\beta$-glucopyranosyloxyuronic acid]-16hydroxy-5 $\alpha, 14 \beta$-poriferast-16-ene-15,23-dione

White amorphous solid; $[\alpha]_{\mathrm{D}}{ }^{20}+19.1(c$ 0.19, $\mathrm{MeOH})$; UV (MeOH): $\lambda_{\max }(\log \varepsilon) 264$ (4.38) nm; CD (MeOH, c 3.8x10-4 M) $\theta\left(\lambda_{\max } \mathrm{nm}\right)-5(220),+13$ (262), -4 (289), +4 (327) mdeg; IR (thin film): $v_{\max } 3496,1692,1640,1199,1132 \mathrm{~cm}^{-1} ;{ }^{1} \mathrm{H}$ NMR see Table $1 ;{ }^{13} \mathrm{C}$ NMR see Table 2; HRESI-MS (-): $m / z$ 795.4214 [M-H] ${ }^{-}$(calcd for $\mathrm{C}_{41} \mathrm{H}_{63} \mathrm{O}_{15}, 795.4167$ ).

Methyl ester of pandaroside $A$ (2)

White amorphous solid; $[\alpha]_{\mathrm{D}}{ }^{20}+7.8(c 0.27, \mathrm{MeOH}) ;{ }^{1} \mathrm{H}$ NMR $\left(500 \mathrm{MHz}, \mathrm{CD}_{3} \mathrm{OD}\right)$ for the uronic residue: $\delta 4.60$ (d, $J=7.5 \mathrm{~Hz}, \mathrm{H}-1^{\prime}$ ), 3.43 (t, $J=7.5 \mathrm{~Hz}, \mathrm{H}-2$ '), 3.56 (m, H-3' and H4'), 3.85 (d, $J=9.0 \mathrm{~Hz}, \mathrm{H}-5$ '), 3.76 (s, $\left.\mathrm{CH}_{3} \mathrm{O}-\right)$ ) ${ }^{13} \mathrm{C} \mathrm{NMR}\left(125 \mathrm{MHz}, \mathrm{CD}_{3} \mathrm{OD}\right)$ for the uronic residue: 102.0 (C-1'), 82.8 (C-2'), 73.1 (C-3’), 77.1 (C-4'), 76.6 (C-5'), 171.3 (C-6'), 53.0 $\left(\mathrm{CH}_{3} \mathrm{O}-\right)$; ESI-MS $m / z 811.4[\mathrm{M}+\mathrm{H}]^{+}$. 


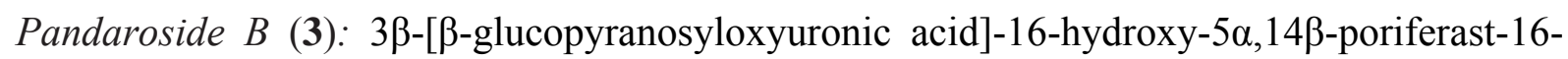
ene-15,23-dione

White amorphous solid; $[\alpha]_{\mathrm{D}}{ }^{24}+12.3$ (c 0.16, MeOH); UV (MeOH): $\lambda_{\max }(\log \varepsilon) 264(3.50)$ nm; CD (MeOH, c 3.9x10-4 M) $\theta \mathrm{nm}\left(\lambda_{\max }\right)-3(220),+10$ (262), -4 (285), +4 (327) mdeg; IR (thin film): $v_{\max } 3338,1731,1677,1199 \mathrm{~cm}^{-1} ;{ }^{1} \mathrm{H}$ NMR see Table $1 ;{ }^{13} \mathrm{C}$ NMR see Table 2; HRESI-MS (-): $m / z 633.3625$ [M-H] $]^{-}$(calcd for $\mathrm{C}_{35} \mathrm{H}_{53} \mathrm{O}_{10}, 633.3639$ ).

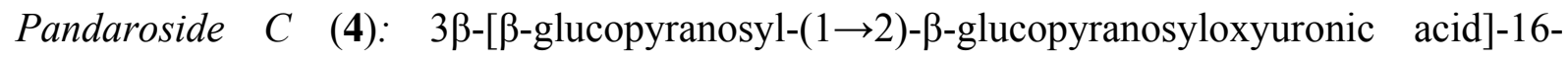
hydroxy-5 $\alpha, 14 \beta$-cholest-16-ene-15,23-dione

White amorphous solid; $[\alpha]_{\mathrm{D}}{ }^{20}+35.2(c 0.10, \mathrm{MeOH})$; UV $(\mathrm{MeOH}): \lambda_{\max }(\log \varepsilon) 264(3.42)$ nm; CD (MeOH, c 3.9x10 $\left.0^{-4} \mathrm{M}\right) \theta\left(\lambda_{\max } \mathrm{nm}\right)-8(220),+7$ (262), -3 (285), +4 (330) mdeg; IR (thin film): $v_{\max } 3385,1679,1201,1176 \mathrm{~cm}^{-1} ;{ }^{1} \mathrm{H}$ NMR see Table $1 ;{ }^{13} \mathrm{C}$ NMR see Table 2; HRESI-MS (-): $m / z 767.3834$ [M-H] $^{-}$(calcd for $\mathrm{C}_{39} \mathrm{H}_{59} \mathrm{O}_{15}, 767.3854$ ).

Methyl ester of pandaroside $C$ (5)

White amorphous solid; $[\alpha]_{\mathrm{D}}{ }^{20}+24.8(c 0.10, \mathrm{MeOH}) ;{ }^{1} \mathrm{H}$ NMR $\left(500 \mathrm{MHz}, \mathrm{CD}_{3} \mathrm{OD}\right)$ for the uronic residue: $\delta 4.60$ (d, $J=7.5 \mathrm{~Hz}, \mathrm{H}-1^{\prime}$ ), 3.44 (t, $J=7.5 \mathrm{~Hz}, \mathrm{H}-2$ '), 3.56 (m, H-3' and H4'), 3.85 (d, $J=9.0 \mathrm{~Hz}, \mathrm{H}-5$ '), 3.76 (s, $\left.\mathrm{CH}_{3} \mathrm{O}-\right)$; ${ }^{13} \mathrm{C} \mathrm{NMR}\left(125 \mathrm{MHz}, \mathrm{CD}_{3} \mathrm{OD}\right)$ for the uronic acid residue: 102.0 (C-1'), 82.8 (C-2'), 73.1 (C-3'), 77.1 (C-4'), 76.6 (C-5'), 171.3 (C-6'), $53.0\left(\mathrm{CH}_{3} \mathrm{O}-\right)$; ESI-MS $m / z 783.5[\mathrm{M}+\mathrm{H}]^{+}$.

Pandaroside D (6): 3 $\beta$-( $\beta$-glucopyranosyloxyuronic acid)-16-hydroxy-5 $\alpha, 14 \beta$-cholest-16-ene15,23-dione

White amorphous solid; $[\alpha]_{\mathrm{D}}{ }^{20}+45.1(c 0.10, \mathrm{MeOH})$; UV $(\mathrm{MeOH}): \lambda_{\max }(\log \varepsilon) 264(3.85)$ $\mathrm{nm}$; CD (MeOH, c 5.0x10-4 M) $\theta\left(\lambda_{\max } \mathrm{nm}\right)-12(218),+10$ (262), -6 (287), +5 (330) mdeg; IR (thin film): $v_{\max } 3412,1697,1677,1196 \mathrm{~cm}^{-1} ;{ }^{1} \mathrm{H}$ NMR see Table $1 ;{ }^{13} \mathrm{C}$ NMR see Table 2; HRESI-MS (-): $m / z$ 605.3313 [M-H] $]^{-}$(calcd for $\mathrm{C}_{33} \mathrm{H}_{49} \mathrm{O}_{10}, 605.3326$ ).

Methyl ester of pandaroside $D(7)$

White amorphous solid; $[\alpha]_{\mathrm{D}}{ }^{20}+35.0(c 0.10, \mathrm{MeOH}) ;{ }^{1} \mathrm{H} \mathrm{NMR}\left(500 \mathrm{MHz}, \mathrm{CD}_{3} \mathrm{OD}\right)$ for the uronic residue: $\delta 4.44$ (d, $J=8.0 \mathrm{~Hz}, \mathrm{H}-1^{\prime}$ ), 3.16 (dd, $\left.J=9.0,8.0 \mathrm{~Hz}, \mathrm{H}-2^{\prime}\right), 3.36$ (t, $J=9.0$ $\mathrm{Hz}, \mathrm{H}-3$ ') 3.50 (t, $J=9.0 \mathrm{~Hz}, \mathrm{H}-4$ ') 3.83 (d, $J=9.0 \mathrm{~Hz}, \mathrm{H}-5$ '), 3.76 (s, $\left.\mathrm{CH}_{3} \mathrm{O}-\right)$; ${ }^{13} \mathrm{C} \mathrm{NMR}$ (125 MHz, $\mathrm{CD}_{3} \mathrm{OD}$ ) for the uronic residue: 103.0 (C-1'), 74.9 (C-2'), 77.4 (C-3'), 73.3 (C-4'), 76.8 (C-5'), 171.5 (C-6'), 52.9 ( $\left.\mathrm{CH}_{3} \mathrm{O}-\right)$; ESI-MS m/z $621.4[\mathrm{M}+\mathrm{H}]^{+}$.

Insert Tables 1 and 2 


\section{Results and discussion}

\subsection{Structural elucidation}

The $\mathrm{CH}_{2} \mathrm{Cl}_{2} / \mathrm{MeOH}$ (1:1) extract of the Caribbean marine sponge Pandaros sp. was fractionated by $\mathrm{RP}-\mathrm{C}_{18}$ flash chromatography and one fraction was further subjected to RP$\mathrm{C}_{18}$ column chromatography and purified by RP- $\mathrm{C}_{18}$ semi-preparative HPLC to yield seven new compounds 1-7. The NMR spectroscopic features of metabolites 1-7 (Tables 1 and 2) were similar and suggested sugar residues linked to a steroidal moiety.

\section{Insert Figure 1.}

Pandaroside A (1): Compound 1 (Figure 1) was isolated as a white amorphous solid with a molecular formula of $\mathrm{C}_{41} \mathrm{H}_{64} \mathrm{O}_{15}$ which was established by the HRESIMS spectrum $(\mathrm{m} / \mathrm{z}$ 795.4214 [M-H] $\left.^{-}, \Delta=5.9 \mathrm{ppm}\right)$. The bands at 3496,1692 , and $1640 \mathrm{~cm}^{-1}$ in the IR spectrum suggested the presence of hydroxyl and carbonyl moieties. The UV spectrum of 1 showing a maximum at $264 \mathrm{~nm}(\log \varepsilon 4.38)$ suggested the presence of a conjugated carbonyl function. The ${ }^{13} \mathrm{C}$ NMR spectrum of 1 displayed 41 carbon signals, 29 corresponding to the aglycon part and 12 to the diglycoside. The ${ }^{1} \mathrm{H}$ NMR spectrum exhibited characteristic steroid signals: two tertiary methyl groups at $\delta_{\mathrm{H}} 0.81(\mathrm{~s}, \mathrm{H}-19)$ and $1.17(\mathrm{~s}, \mathrm{H}-18)$, three secondary methyl groups at $\delta_{\mathrm{H}} 0.89(\mathrm{~d}, J=6.5 \mathrm{~Hz}, \mathrm{H}-26), 0.90(\mathrm{~d}, J=6.5 \mathrm{~Hz}, \mathrm{H}-27)$, and 1.15 (d, $J=7.0 \mathrm{~Hz}, \mathrm{H}-$ 21 ), and one primary methyl group at $\delta_{\mathrm{H}} 0.76\left(\mathrm{t}, J=7.5 \mathrm{~Hz}, \mathrm{H}-24^{2}\right)$. All these data were consistent with a poriferastane/stigmastane skeleton. The ${ }^{13} \mathrm{C}$ NMR spectrum confirmed the presence of two anomeric carbons at $\delta_{\mathrm{C}} 101.9$ (C-1') and 105.3 (C-1") and also revealed the presence of a tetra-substituted double bond at $\delta_{\mathrm{C}} 151.5$ (C-16) and 154.9 (C-17), a carboxylic acid at $\delta_{\mathrm{C}} 172.4$ (C-6'), and two carbonyls at $\delta_{\mathrm{C}} 206.1$ (C-15) and 215.8 (C-23). The usual $\mathrm{A}, \mathrm{B}$ and $\mathrm{C}$ rings of the steroidal aglycon part was established by COSY and HMBC correlations, and by comparison with literature data. The key H-14/H-20/H-22/H-18/C-17, and $/ \mathrm{H}-20 / \mathrm{H}-14 / \mathrm{H}-8 / \mathrm{C}-16$ HMBC correlations allowed us to build the unusual cyclopentenone D ring of the aglycon part (Figure 2). A hydroxyl at C-16 was the only possibility to fit the molecular formula. The 2-hydroxycyclopentenone D ring was further confirmed by comparison with the ${ }^{13} \mathrm{C}$ NMR data of stemmosides $\mathrm{E}$ and $\mathrm{F}\left[\delta_{\mathrm{C}} 43.3(\mathrm{C}-13)\right.$, 54.5 (C-14), 206.7 (C-15), 152.2 (C-16), 152.9 (C-17), 25.5 (C-18) ppm], the other unique examples of natural compounds exhibiting such a D ring [8]. The structure of the side chain was deduced from the key C-23/H-20/H-22/H-24/H-24 ${ }^{1}$ HMBC correlations. The relative 
stereochemistry of the aglycon part was established on the basis of detailed NOESY spectrum analysis. Observation of $\mathrm{H}-8 / \mathrm{H}-18 / \mathrm{H}-19$ NOEs placed these protons on the same side. Whereas the characteristic chemical shift of C-19 at $\delta_{\mathrm{C}} 11.2$ was in agreement with the transtrans relative configuration for the $\mathrm{A} / \mathrm{B}$ and $\mathrm{B} / \mathrm{C}$ ring junctions, the chemical shift of $\mathrm{C}-18$ at $\delta_{\mathrm{C}} 25.9$ did not allow us to assign C-D ring junction unambiguously. A small H-14/H-18 NOE suggested a cis $\mathrm{C} / \mathrm{D}$ junction. This unusual $\beta$ configuration at $\mathrm{C}-14$ was further confirmed by examination of previous studies which showed that a downfield signal for $\mathrm{H}-7 \alpha$ at $\delta_{\mathrm{H}} 2.17$ $(1 \mathrm{H}, \mathrm{qd}, J=12.5,4.5 \mathrm{~Hz})$ was consistent was a cis C-D junction [9]. This downfield resonance of $\mathrm{H}-7 \alpha$ could be explained because it lies in the deshielding cone of the carbonyl group. The configuration at H-3 was assigned as $\alpha$ on the basis of its vicinal coupling constants of $J=11.5$ and $4.5 \mathrm{~Hz}\left(\delta_{\mathrm{H}} 3.64 \mathrm{ppm}\right.$, tt). For the configurational assignment of the steroidal aglycon part we decided to use quantum-mechanical calculational of the CD spectrum which was then compared with the experimental one $[10,11]$. The cyclopentenone and the ketone gave rise to three chromophores with alternative signs [327 $(\Delta \varepsilon=+2.5), 290(-$ 7.5), $262(+10.2) \mathrm{nm}]$ on the experimental CD spectrum. The similar ${ }^{13} \mathrm{C}$ NMR data of 1 with those of phytosterone, the unique example of 23-oxocholestane suggested a C-24 $R$ configuration for 1 [12], and the usual absolute configurations for the tetracycle of steroids suggested an $\alpha$ orientation for H-14. A conformational analysis was performed on this stereoisomer with the DFT method at B3LYP/6-31+G* level which gave 43 conformers of relative energies below $2 \mathrm{kcal} \mathrm{mol}^{-1}$. Because of the high number of conformers the calculation was run on the lowest energy DFT structure (Figure 3) [13]. A very good agreement was observed between the experimental CD spectrum of 1 in the gas phase and the DFT calculated structure of $\mathbf{1}$ with this stereochemistry which allowed us to propose this absolute configuration for the aglycon part of $\mathbf{1}$.

Insert Figures 2 and 3

Compound 1 contained two sugar residues at C-3 evidenced by the two anomeric protons at $\delta_{\mathrm{H}} 4.60\left(1 \mathrm{H}, \mathrm{d}, J=7.5 \mathrm{~Hz}, \mathrm{H}-1^{\prime}\right)$ and $4.56(1 \mathrm{H}, \mathrm{d}, J=8.0 \mathrm{~Hz}, \mathrm{H}-1$ '), one being an uronic derivative due to the presence of a carboxylic acid signal at $\delta_{\mathrm{C}} 172.4$. The COSY spectrum and the coupling constants indicated that the two sugar residues were a glucose and a glucuronic acid $[8,14]$. A C-3/H-1' HMBC correlation placed the glucuronic acid at the C-3 position of the aglycon, whereas a H-1"/C-2' HMBC correlation indicated that the glucose was linked to the glucuronic acid through the oxygen at C-2'. The large $J$ values of the signals 
H-1' and H-1" (d, 7.5 and d, 8.0 Hz) showed that both sugars and the aglycon were connected through $\beta$-glycosidic linkages. The limiting quantity of $\mathbf{1}$ did not allow us to assign the absolute configuration of the sugar residues.

A minor compound 2 was isolated during the purification process of $\mathbf{1}$. The $\mathrm{m} / \mathrm{z}$ at 811.4 $[\mathrm{M}+\mathrm{H}]^{+}$indicated the presence of an additional methylene unit in comparison with 1 . The ${ }^{1} \mathrm{H}$ and ${ }^{13} \mathrm{C}$ NMR data were almost identical to those of 1 except for the new signals at $\delta_{\mathrm{H}} 3.76(\mathrm{~s}$, $\left.\underline{\mathrm{H}}_{3}-\mathrm{CO}\right)$ and $\delta_{\mathrm{C}} 53.0\left(\mathrm{O}-\underline{\mathrm{CH}}_{3}\right)$ which suggested the presence of a methoxy group. Compound 2 was shown to be the methyl ester of the glucuronic acid of pandaroside A (1) by the observation of a strong C-6' $/ \underline{\mathrm{H}}_{3} \mathrm{CO} \mathrm{HMBC}$ correlation. Firstly 2 was thought to be an artefact of the purification process of $\mathbf{1}$. Its presence was evidenced by LC-MS after extraction by $\mathrm{CH}_{2} \mathrm{Cl}_{2} / \mathrm{MeOH}$ but we assumed that esterification could not occur during this step. We then concluded that the methyl ester 2 was produced by the organism or its associated microorganisms and is not an artefact of the purification process.

Pandaroside B (3): Compound 3 was isolated as a white amorphous solid with a molecular formula of $\mathrm{C}_{35} \mathrm{H}_{54} \mathrm{O}_{10}$ which was deduced from the HRESI-MS spectrum $(\mathrm{m} / z$ 633.3625 [M$\left.\mathrm{H}]^{-}, \Delta=-1.2 \mathrm{ppm}\right)$. A detailed comparison of NMR data of the aglycon part of compound 3 with those of compounds 1 and 2 revealed that all compounds possessed the same skeleton. The presence of only one anomeric proton at $\delta_{\mathrm{H}} 4.43(\mathrm{~d}, J=8.0 \mathrm{~Hz}, \mathrm{H}-1$ ') indicated that only one sugar residue was connected at C-3. COSY correlations and the signal at $\delta_{\mathrm{C}} 171.9$ allowed us to prove that the sugar residue was the same glucoronic acid as in $\mathbf{1}$.

Pandaroside C (4): Compound 4 was isolated as a white amorphous solid with a molecular formula of $\mathrm{C}_{39} \mathrm{H}_{60} \mathrm{O}_{15}$ which was deduced from the HRESI-MS spectrum $(\mathrm{m} / z$ 767.3834 [M$\left.\mathrm{H}]^{-}, \Delta=-1.9 \mathrm{ppm}\right)$. The ${ }^{1} \mathrm{H}$ and ${ }^{13} \mathrm{C}$ NMR data were also quite similar to those of pandaroside A (1), which indicated the occurrence of a similar steroidal saponin skeleton. Compared to $\mathbf{1}$, 4 had a 28 amu difference which suggested the loss of two methylene units. Differences were easily located on the aglycon side chain where the lack of the characteristic signal at $\delta_{\mathrm{H}} 0.76$ $\left(\mathrm{t}, J=7.5, \mathrm{H}_{3}-24^{2}\right)$ suggested that the ethyl was absent from C-24. The AB signals at $\delta_{\mathrm{H}} 2.96$ (dd, $J=17.5,4.5 \mathrm{~Hz}, \mathrm{H}-22 \mathrm{a})$ and 2.79 (dd, $J=17.5,9.0 \mathrm{~Hz}, \mathrm{H}-22 \mathrm{~b}$ ) were also replaced by a signal at $\delta_{\mathrm{H}} 2.85$ (m, H-22a and b).

A minor compound 5 was isolated during the purification process of $\mathbf{4}$, which was assigned as the methyl ester of $\mathbf{4}$ in a manner similar to that used to assign the structure of compound 2.

Pandaroside D (6): Compound 6 was isolated as a white amorphous solid with a molecular formula of $\mathrm{C}_{33} \mathrm{H}_{50} \mathrm{O}_{10}$ which was deduced from the HRESI-MS spectrum $(\mathrm{m} / z$ 605.3313 [M$\left.\mathrm{H}]^{-}, \Delta=-1.19 \mathrm{ppm}\right)$. Comparison of NMR data of the $\mathbf{4}$ and $\mathbf{6}$ aglycon parts clearly indicated 
that $\mathbf{6}$ also possessed a cholestane skeleton. The sugar moiety of $\mathbf{6}$ was identical to that of $\mathbf{3}$ with only one glucuronic acid at C-3.

Here also, a minor compound $\mathbf{7}$ was isolated during the purification process of $\mathbf{6}$, which was assigned as the methyl ester of $\mathbf{6}$ in a manner similar to that used to assign the structure of compound 2.

All absolute and relative configurations of compounds 2-7 were assumed to be the same as for 1 because of very similar NOESY and CD spectra.

For all the isolated compounds, no antitumor activity against three human tumor cell lines (A549 lung cancer cells, HT29 colonic cancer cells, and MDA-MB-231 breast cancer cells) was detected below $10 \mu \mathrm{gL}^{-1}$.

\section{Acknowledgements}

We are grateful to PharmaMar Madrid for financial support also provided by a grant (N. C.) of the Provence-Al pes-Côte d'Azur Region. We are also grateful to UNESCO by a grant (E.L.R). We thank J. Vacelet (Centre d'Océanologie de Marseille) for careful taxonomical sponge identification, M. Gaysinski and the PFTC of Nice for assistance in recording the NMR spectroscopic experiments, and J.-M. Guigonis for assistance in recording the HRMS experiments. We finally thank Mr le préfet de la Martinique and the DIREN for their help in the collection of Caribbean marine invertebrates

Supplementary information: picture of the sponge specimen, ${ }^{1} \mathrm{H},{ }^{13} \mathrm{C}, \mathrm{COSY}$, HSQC, HMBC spectra of $\mathbf{1},{ }^{1} \mathrm{H},{ }^{13} \mathrm{C}$, HMBC spectra of $2,{ }^{1} \mathrm{H},{ }^{13} \mathrm{C}$ spectra of $\mathbf{3}$ and $\mathbf{4},{ }^{1} \mathrm{H}$ spectrum of $5,{ }^{1} \mathrm{H}$, ${ }^{13} \mathrm{C}$ spectra of $\mathbf{6}$ and $\mathbf{7}$. 


\section{References}

[1] Iorizzi M, De Marino S, Zollo F. Steroidal oligoglycosides from the Asteroidea. Curr Org Chem 2001;5:951-73.

[2] Schmitz FJ, Ksebati MB, Gunasekera SP, Agarwal S. Sarasinoside A1: a Saponin containing amino sugars isolated from a sponge. J Org Chem 1988; 53:5941-7.

[3] Kitagawa I, Kobayashi M, Okamomoto Y, Yoshikawa M, Hamamoto Y. Sarasinosides A1, B1, C1; norlanostane-triterpenoid oligoglycosides from sponge Asteropus saeasinosum. Chem Pharm Bull 1987;35:5036-9.

[4] Takada K, Nakao Y, Matsunaga S, van Soest RWM, Fusetani N. Nobiloside, a new neuraminidase inhibitory triterpenoidal saponin from the marine sponge Erylus nobilis. $\mathrm{J}$ Nat Prod 2002;65:411-3.

[5] Dai H-F, Edrada RA, Ebel R, Nimtz R, Wray V, Proksch P. Norlanostane triterpenoidal saponins from the marine sponge Melophlus sarassinorum. J Nat Prod 2005;68:1231-7 and references cited therein.

[6] Berlinck RGS, Burtoloso ACB, Kossuga MH. The chemistry and biology of organic guanidine derivatives. Nat Prod Rep 2008;25:919-54.

[7] Schmitz FJ, Prasad RS, Gopichand Y, Hossain MB, Van der Helm D, Schmidt P. Acanthifolicin, a new episulfide-containing polyether carboxylic acid from extracts of the marine sponge Pandaros acanthifolium. J Am Chem Soc 1981;103:2467-9.

[8] Plaza A, Perrone A, Balesrieri ML, Felice F, Balestrieri C, Hamed AI, Pizza C, Piacente S. New unusual pregnane glycosides with antiproliferative activity from Solenostemma argel. Steroids 2005;70:594-603.

[9] Jung ME, Johnson TW. First total synthesis of xestobergsterol A and active structural analogues of the xestobergsterols. Tetrahedron 2001;57:1449-81.

[10] Bringmann G, Gulder TAM, Reichert M, Gulder T. The online assignment of the absolute configuration of natural products: HPLC-CD in combination with quantum chemical CD calculations. Chirality 2008;20:628-42.

[11]Krohn K, Kock I, Elsesser B, Floerke U, Schulz B, Draeger S, Pescitelli G, Antus S, Kurtan T. Bioactive natural products from the endophytic fungus Ascochyta sp. from Meliotus dentatus - Configurational assignment by solid-state CD and TDDFT calculations. Eur J Org Chem 2007:1123-9.

[12]Li GP, Zhao JF, Tu YQ, Yang XD, Zhang HB, Li L. A new phytosterone from Passiflora wilsonii. Chinese Chem Lett 2004;15:659-60. 
[13] All the calculations were performed at $298 \mathrm{~K}$ by the Gaussian03 program package. The Density Functional Theory (DFT) was used to scan the potential energy surface (PES) at the B3LYP/6+31G* level to identify conformers. Ground-state geometries were optimized at the B3LYP $/ 6+31 \mathrm{G}^{*}$ level. TDDFT was employed to calculate excitation energy (in $\mathrm{eV}$ ) and rotatory strength $R$ in dipole velocity $\left(R_{\mathrm{vel}}\right)$ and dipole length $\left(R_{\text {len }}\right)$ forms. The calculated rotatory strengths were simulated in ECD curve by using the Gaussian function:

$$
\Delta g(E)=\frac{1}{2.297 \times 10^{-99}} \frac{1}{\sqrt{2 \pi c}} \sum_{t}^{A} \Delta E_{i} R_{t} e^{-\left(\frac{\left(E-\Delta E_{i}\right)}{2 \sigma}\right)^{2}}
$$

where $\sigma$ is the width of the band at $\underset{\xi}{\frac{1}{\xi}}$ height and $\Delta E_{\ell}$ and $R_{i}$ are the excitation energies and the rotatory strengths for transition $i$, respectively, $\sigma=0.20 \mathrm{eV}$ and $R_{v \varepsilon !}$ were used.

Frisch MJ, Trucks GW, Schlegel HB, Scuseria GE, Robb MA, Cheeseman JR, Montgomery JA, Vreven T, Kudin KN, Burant JC, Millam JM, Iyengar SS, Tomasi J, Barone V, Mennucci B, Cossi M, Scalmani G, Rega N, Petersson GA, Nakatsuji H, Hada M, Ehara M, Toyota K, Fukuda R, Hasegawa J, Ishida M, Nakajima T, Honda Y, Kitao O, Nakai H, Klene M, Li X, Knox JE, Hratchian HP, Cross JB, Adamo C, Jaramillo J, Gomperts R, Stratmann RE, Yazyev O, Austin AJ, Cammi R, Pomelli C, Ochterski JW, Ayala PY, Morokuma K, Voth GA, Salvador P, Dannenberg JJ, Zakrzewski VG, Dapprich S, Daniels AD, Strain MC, Farkas O, Malick DK, Rabuck AD, Raghavachari K, Foresman JB, Ortiz JV, Cui Q, Baboul AG, Clifford S, Cioslowski J, Stefanov BB, Liu G, Liashenko A, Piskorz P, Komaromi I, Martin RL, Fox DJ, Keith T, Al-Laham MA, Peng CY, Nanayakkara A, Challacombe M, Gill PMW, Johnson B, Chen W, Wong MW, Gonzalez C, Pople JA. Gaussian 03, Revision C.01, Gaussian, Inc., Wallingford CT, 2004.

[14] Harding JR, King CD, Perrie JA, Sinnott D, Stachulski AV. Glucuronidation of steroidal alcohols using iodosugar and imidate donors. Org Biomol Chem 2005;3:1501-7. 
Table $1-{ }^{1} \mathrm{H}$ NMR data (500 MHz, $\mathrm{CD}_{3} \mathrm{OD}$ ) for compounds $\mathbf{1 , 3 , 4 , 6} \delta$ in ppm (multiplicity, $J$ in $\mathrm{Hz}$ )

\begin{tabular}{|c|c|c|c|c|}
\hline No. & 1 & 3 & 4 & 6 \\
\hline $1 \beta$ & $1.68(m)$ & $1.64(m)$ & $1.68(m)$ & $1.64(m)$ \\
\hline $1 \alpha$ & $0.86(m)$ & $0.86(m)$ & $0.86(m)$ & $0.86(m)$ \\
\hline $2 \alpha$ & $1.86(m)$ & $1.83(m)$ & $1.86(m)$ & $1.84(m)$ \\
\hline $2 \beta$ & $1.49(\mathrm{~m})$ & $1.50(\mathrm{~m})$ & $1.49(m)$ & $1.50(\mathrm{~m})$ \\
\hline 3 & $3.64(t t, 11.54 .5)$ & $3.63(m)$ & $3.64(m)$ & $3.63(m)$ \\
\hline $4 \alpha$ & $1.72(m)$ & $1.72(m)$ & $1.72(m)$ & $1.72(m)$ \\
\hline $4 \beta$ & $1.28(\mathrm{~m})$ & $1.28(\mathrm{~m})$ & $1.28(\mathrm{~m})$ & $1.28(\mathrm{~m})$ \\
\hline 5 & $1.04(m)$ & $1.04(m)$ & $1.04(m)$ & $1.04(m)$ \\
\hline $6 \alpha$ & $1.35(m)$ & $1.35(m)$ & $1.35(m)$ & $1.35(m)$ \\
\hline $6 \beta$ & $1.30(\mathrm{~m})$ & $1.30(\mathrm{~m})$ & $1.30(\mathrm{~m})$ & $1.30(m)$ \\
\hline $7 \alpha$ & $2.17(q d, 12.54 .5)$ & $2.17(m)$ & $2.17(m)$ & $2.17(m)$ \\
\hline $7 \beta$ & $1.66(\mathrm{~m})$ & $1.65(\mathrm{~m})$ & $1.66(\mathrm{~m})$ & $1.65(\mathrm{~m})$ \\
\hline 8 & $1.94(m)$ & $1.93(m)$ & $1.94(m)$ & $1.93(m)$ \\
\hline 9 & $0.88(m)$ & $0.87(m)$ & $0.88(m)$ & $0.87(m)$ \\
\hline $11 \beta$ & $1.39(m)$ & $1.37(m)$ & $1.39(m)$ & $1.37(m)$ \\
\hline $11 \alpha$ & $1.17(m)$ & $1.15(m)$ & $1.17(m)$ & $1.15(m)$ \\
\hline $12 \beta$ & $1.55(\mathrm{~m})$ & $1.55(\mathrm{~m})$ & $1.55(\mathrm{~m})$ & $1.55(m)$ \\
\hline $12 \alpha$ & $1.47(m)$ & $1.47(m)$ & $1.47(m)$ & $1.47(m)$ \\
\hline 14 & $1.83(d, 4.5)$ & $1.83(d, 4.5)$ & $1.83(d 4.5)$ & $1.83(d, 4.5)$ \\
\hline 18 & $1.17(s)$ & $1.15(s)$ & $1.17(s)$ & $1.15(s)$ \\
\hline 19 & $0.81(s)$ & $0.81(s)$ & $0.81(s)$ & $0.81(s)$ \\
\hline 20 & $2.88(m)$ & $2.83(m)$ & $2.83(m)$ & $2.83(m)$ \\
\hline 21 & $1.15(d, 4.5)$ & $1.14(d, 7 \mathrm{~Hz})$ & $1.15(d, 4.5)$ & $1.14(d, 4.5)$ \\
\hline $22 a$ & $2.96(d d, 17.54 .5)$ & $2.87(d d, 17.5,4.5)$ & & \\
\hline $22 b$ & $2.79(d d, 17.59 .0)$ & $2.79(d d, 17.5,8.5)$ & $2.85(m)$ & $2.85(m)$ \\
\hline 24 & $2.23(d d d, 10.07 .54 .0)$ & $2.23(\mathrm{~m})$ & $2.31(d, 7)$ & $2.31(d, 7)$ \\
\hline $24^{1} a$ & $1.57(\mathrm{~m})$ & $1.57(m)$ & & \\
\hline $24^{1} \mathrm{~b}$ & $1.51(\mathrm{~m})$ & $1.51(\mathrm{~m})$ & & \\
\hline $24^{2}$ & $0.76(t, 7.5)$ & $0.76(t, 7.5)$ & & \\
\hline 25 & $1.88(m)$ & $1.88(m)$ & $2.10(m)$ & $2.08(m)$ \\
\hline \multirow{2}{*}{$26 / 27$} & $0.89(d, 6.5)$ & $0.89(d, 6.5)$ & $0.89(d, 6.5)$ & $0.89(d, 6.5)$ \\
\hline & $0.90(d, 6.5)$ & $0.90(d, 6.5)$ & $0.90(d, 6.5)$ & $0.90(d, 6.5)$ \\
\hline $1^{\prime}$ & $4.60(d, 7.5)$ & $4.43(d, 8.0)$ & $4.60(d, 7.5)$ & $4.43(d, 8.0)$ \\
\hline $2^{\prime}$ & $3.45(d d, 9.08 .0)$ & $3.18(d d, 9.08 .0)$ & $3.45(d d, 9.08 .0)$ & $3.18(d d, 9.08 .0)$ \\
\hline $3^{\prime}$ & $3.57(t, 9.5)$ & $3.36(t, 9.0)$ & $3.57(t, 9.5)$ & $3.36(t, 9.0)$ \\
\hline $4^{\prime}$ & $3.56(d, 10.0)$ & $3.51(t, 9.0)$ & $3.56(d, 10.0)$ & $3.51(t, 9.0)$ \\
\hline $5^{\prime}$ & $3.79(t, 9.5)$ & $3.78(d, 9.5)$ & $3.79(t, 9.5)$ & $3.78(d, 9.5)$ \\
\hline 1" & $4.56(d, 8.0)$ & & $4.56(d, 8.0)$ & \\
\hline 2" & $3.23(d d, 9.08 .0)$ & & $3.23(d d, 9.08 .0)$ & \\
\hline 3" & $3.37(t, 9.0)$ & & $3.37(t, 9.0)$ & \\
\hline 4" & $3.33(m)$ & & $3.33(m)$ & \\
\hline $5 "$ & $3.27(d d d, 12.05 .02 .5)$ & & $3.27(d d d, 12.05 .02 .5)$ & \\
\hline $6 " a$ & $3.84(d d, 11.52 .5)$ & & $3.84(d d, 11.52 .5)$ & \\
\hline 6"b & $3.70(d d, 11.55 .0)$ & & $3.70(d d, 11.55 .0)$ & \\
\hline
\end{tabular}


Table $2-{ }^{13} \mathrm{C}$ NMR data $\left(125 \mathrm{MHz}, \mathrm{CD}_{3} \mathrm{OD}\right)$ for compounds $\mathbf{1}, \mathbf{3 , 4} \mathbf{4}$ : $\delta$ in ppm.

\begin{tabular}{|c|c|c|c|c|}
\hline No. & 1 & 3 & 4 & 6 \\
\hline 1 & 37.5 & 37.5 & 37.5 & 37.5 \\
\hline 2 & 30.1 & 30.1 & 30.1 & 30.1 \\
\hline 3 & 80.9 & 79.8 & 80.9 & 80.0 \\
\hline 4 & 35.5 & 35.4 & 35.5 & 35.4 \\
\hline 5 & 45.7 & 45.7 & 45.7 & 45.7 \\
\hline 6 & 30.3 & 30.3 & 30.3 & 30.3 \\
\hline 7 & 31.4 & 31.4 & 31.4 & 31.4 \\
\hline 8 & 35.2 & 35.2 & 35.2 & 35.2 \\
\hline 9 & 45.9 & 45.9 & 45.9 & 45.9 \\
\hline 10 & 38.3 & 38.3 & 38.3 & 38.3 \\
\hline 11 & 20.0 & 20.0 & 20.0 & 20.0 \\
\hline 12 & 32.7 & 32.7 & 32.7 & 32.7 \\
\hline 13 & 43.8 & 43.8 & 43.7 & 43.7 \\
\hline 14 & 56.2 & 56.2 & 56.2 & 56.2 \\
\hline 15 & 206.1 & 206.1 & 206.1 & 206.1 \\
\hline 16 & 151.4 & 151.5 & 151.4 & 151.4 \\
\hline 17 & 154.9 & 154.9 & 154.9 & 154.6 \\
\hline 18 & 25.9 & 25.9 & 25.9 & 25.9 \\
\hline 19 & 11.2 & 11.2 & 11.2 & 11.2 \\
\hline 20 & 27.4 & 27.3 & 28.1 & 28.1 \\
\hline 21 & 18.0 & 18.0 & 18.0 & 18.0 \\
\hline 22 & 49.0 & 49.0 & 48.1 & 48.1 \\
\hline 23 & 215.8 & 215.8 & 212.4 & 212.4 \\
\hline 24 & 61.9 & 61.9 & 53.4 & 53.4 \\
\hline $24^{1}$ & 22.3 & 22.3 & & \\
\hline $24^{2}$ & 12.4 & 12.4 & & \\
\hline 25 & 30.8 & 30.9 & 25.8 & 25.8 \\
\hline $26 / 27$ & 20.0 & 20.0 & 22.9 & 22.9 \\
\hline $26 / 27$ & 21.5 & 21.5 & 22.9 & 22.9 \\
\hline $1^{\prime}$ & 101.9 & 102.9 & 101.9 & 102.9 \\
\hline $2^{\prime}$ & 82.8 & 74.8 & 82.8 & 74.8 \\
\hline $3^{\prime}$ & 72.9 & 77.5 & 72.9 & 77.5 \\
\hline $4^{\prime}$ & 77.2 & 73.2 & 77.2 & 73.2 \\
\hline $5^{\prime}$ & 76.4 & 76.6 & 76.4 & 76.6 \\
\hline $6^{\prime}$ & 172.4 & 171.9 & 172.4 & 171.9 \\
\hline 1" & 105.3 & & 105.3 & \\
\hline 2" & 76.2 & & 76.2 & \\
\hline 3" & 77.7 & & 77.7 & \\
\hline 4" & 71.4 & & 71.4 & \\
\hline 5" & 78.3 & & 78.3 & \\
\hline 6" & 62.7 & & 62.7 & \\
\hline
\end{tabular}


Figure 1 - Structure of pandarosides A-D and their methyl esters (1-7).

Figure 2 - Key HMBC correlations for a portion of $\mathbf{1}$.

Figure 3 - Measured (gas phase) and calculated CD spectra for the aglycon part of pandaroside A (1) 
Figure 1.

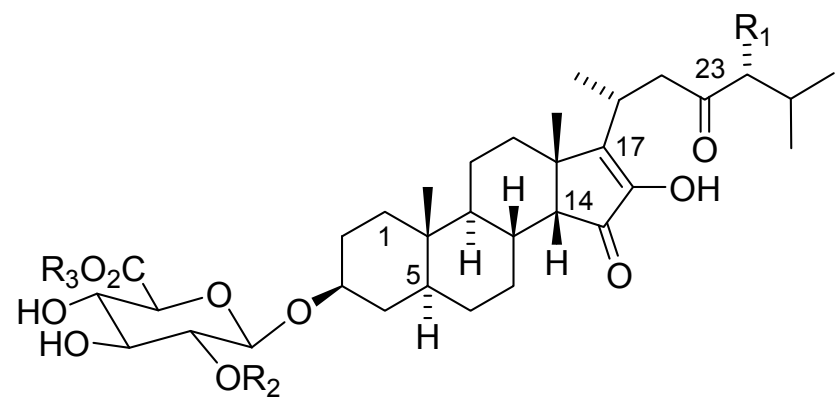

Figure 2.

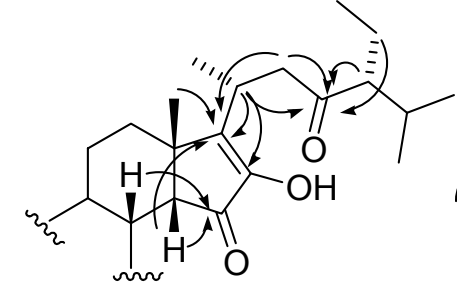

Figure 3.

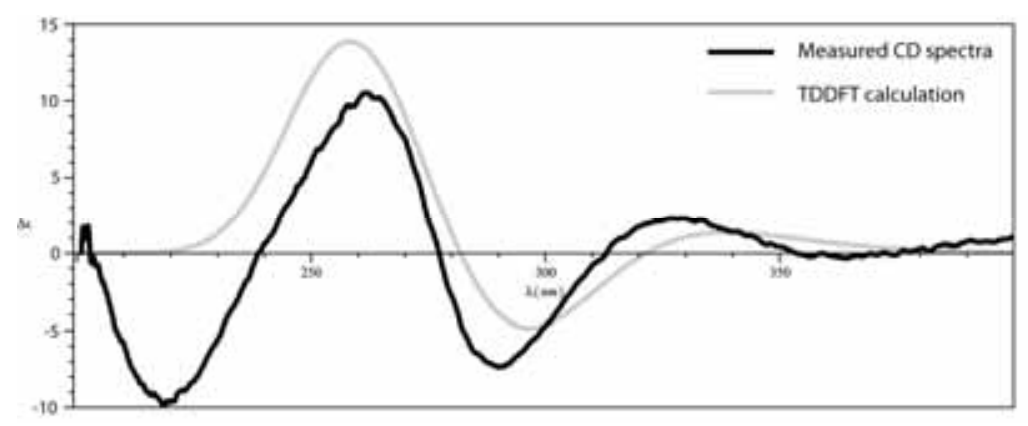

HMBC correlation $(\mathrm{H}-\mathrm{C})$
Pandaroside A (1) $R_{1}=E t, R_{2}=\beta-G l c, R_{3}=H$ $2 R_{1}=E t, R_{2}=\beta-G l c, R_{3}=M e$ Pandaroside B (3) $\mathrm{R}_{1}=\mathrm{Et}, \mathrm{R}_{2}=\mathrm{H}, \mathrm{R}_{3}=\mathrm{H}$ Pandaroside C (4) $R_{1}=H, R_{2}=\beta-G \mid c, R_{3}=H$ $5 R_{1}=H, R_{2}=\beta-G l c, R_{3}=M e$ Pandaroside D (6) $R_{1}=H, R_{2}=H, R_{3}=H$ $7 \mathrm{R}_{1}=\mathrm{H}, \mathrm{R}_{2}=\mathrm{H}, \mathrm{R}_{3}=\mathrm{Me}$

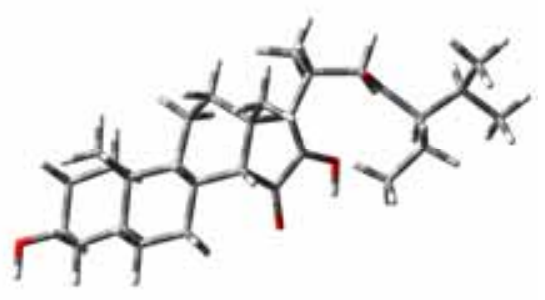

